\title{
Studi Ekstraksi Fitur Berbasis Vektor Word2Vec pada Pembentukan Fitur Berdimensi Rendah
}

\author{
${ }^{1}$ Irwan Budiman, ${ }^{2} \mathrm{M}$ Reza Faisal, \& ${ }^{3}$ Dodon Turianto Nugrahadi \\ 1,2,3 Program Stud Ilmu Komputer, FMIPA, Universitas Lambung Mangkurat, Banjarbaru, Indonesia \\ e-mail: ${ }^{1}$ irwan.budiman@ulm.ac.id, ${ }^{2}$ reza.faisal@ulm.ac.id, ${ }^{3}$ dodonturianto@ulm.ac.id
}

\begin{abstract}
Klasifikasi teks adalah salah satu metode untuk mengelola dan mencari informasi penting yang terdapat pada format tekstual yang tidak terstruktur. Ekstraksi fitur merupakan proses penting pada klasifikasi teks untuk mengubah format tekstual yang tidak terstruktur menjadi terstruktur sehingga dapat diproses oleh algoritma machine learning untuk mengklasifikasikan ke class yang telah ditentukan. Salah satu teknik ekstraksi fitur yang umum digunakan adalah vector space representation. Teknik ini mudah digunakan tetapi berpotensi menghasilkan data dengan dimensi banyak yang berakibat kepada peningkatan waktu komputasi bahkan tidak dapat diproses karena limitasi perangkat keras. Pada riset ini kami melakukan studi terhadap teknik ekstraksi fitur yang mampu menghasilkan data berdimensi sedikit. Ekstraksi fitur yang digunakan memanfaatkan vektor word2vec untuk mengontrol jumlah fitur yang dihasilkan. Pada riset ini kami membandingkan beberapa model yang dihasilkan sendiri dengan jumlah fitur yang bervariasi dan model yang telah disedikan oleh Google. Hal ini dilakukan untuk mengetahui jumlah fitur yang dapat menghasilkan kinerja klasifikasi terbaik. Hasilnya didapat nilai kinerja tertinggi akurasi yaitu 0.877 dengan jumlah fitur adalah 300 dari model yang dihasilkan sendiri.
\end{abstract}

Keywords: word2vec, klasifikasi teks, machine learning, ekstraksi fitur, n-gram.

\section{PENDAHULUAN}

Hampir semua data yang ada sekarang ini disimpan dalam format teks seperti laporan, status atau komentar pada media sosial, review produk dan laporan riset penelitian, berita dan bahkan data biologi seperti untaian protein dan DNA. Contoh-contoh tersebut disimpan dalam format tekstual tidak terstruktur. Sekarang telah banyak riset terkait penemuan informasi dari data teks yang umumnya dikenal dengan istilah text mining [1]. Salah satu bidang pada text mining adalah klasifikasi teks otomatis yang umumnya menggunakan algoritma machine learning [2]. Riset-riset tentang klasifikasi teks telah secara luas membantu menyelesaikan banyak permasalahan berdasarkan jenis data teks. Pada data media sosial, klasifikasi teks dapat membantu tingkat depresi seseorang berdasarkan apa yang dia tulis pada media sosial.[3]. Pada kasus lain, klasifikasi teks membantu mengidentifikasi informasi penting terkait bencana alam [4], menentukan sentimen tentang komentar evaluasi terhadap dosen [5], review film [6] dan berita [7]. Sedangkan teknik klasifikasi teks pada bidang biologi digunakan pada data untaian protein [8] dan DNA [9] [10].

Namun data teks tidak dapat langsung diproses oleh algoritma machine learning, sehingga klasifikasi tidak bisa dilakukan karena algoritma tersebut hanya dapat memproses data terstruktur. Oleh sebab itu data teks yang tidak terstruktur harus terlebih dahulu diubah menjadi data yang terstruktur. Proses ini dikenal dengan istilah ekstraksi fitur. Proses ini sangat penting peranannya pada klasifikasi teks, karena pemilihan metode yang efektif dan tepat dapat mempengaruhi kinerja klasifikasi [8]. Sampai saat ini telah banyak riset-riset yang terkait dengan ekstraksi fitur yang bertujuan untuk meningkatkan kinerja klasifikasi.

Salah satu teknik yang umum digunakan adalah vector space representation yang membentuk data terstruktur dalam bentuk term-frequency matrix [11] [12]. Teknik ini menghasilkan fitur yang sederhana dan telah digunakan pada banyak riset. Pada kasus menggunakan dataset email, data teks dikonversi dengan menggunakan pendekatan Term Frequency-Inverse Document Frequency (TF-IDF) menjadi data terstruktur dan selanjutnya diproses dengan algoritma k-NN pada proses klasifikasi [13]. Teknik TF-IDF juga digunakan pada data ACM Digital Library dan kemudian diproses dengan algoritma klasifikasi Naïve Bayes, Support 
Vector Machine (SVM) dan Random Forest [14]. Pada riset lain digunakan ekstraksi fitur dengan menggunakan pendekatan n-gram pada dataset review film yang didapat dari website IMDB. Pada riset ini digunakan tiga jenis teknik n-gram yaitu unigram, bigram dan trigram. Dan data terstruktur yang dihasilkan diproses dengan empat algoritma klasifikasi yaitu Naïve Bayes, Maximum Entropy, Stochastic Gradien Descent (SGD) dan SVM [6].

Namun teknik-teknik yang disebutkan di atas berpotensi menghasilkan data berdimensi banyak. Untuk membuktikan hal ini kami melakukan studi pendahuluan dengan menggunakan data dan teknik ekstraksi fitur dari riset A. Tripathy dan kawan-kawan [6]. Pada studi pendahuluan ini dilakukan ekstraksi fitur dataset review film dari web IMDB dengan menggunakan beberapa kombinasi teknik yaitu unigram, bigram, trigram, gabungan fitur unigram dan bigram, gabungan fitur bigram dan trigram, terakhir adalah gabungan fitur unigram, bigram dan trigram. Tabel 6 memperlihatkan jumlah fitur dari masing-masing teknik tersebut.

Tabel 6. Jumlah Fitur Setiap Teknik Ekstraksi Fitur

\begin{tabular}{lr}
\hline \multicolumn{1}{c}{ Teknik Ekstraksi Fitur } & Jumlah Fitur \\
\hline Unigram & 32.851 \\
Bigram & 202.575 \\
Trigram & 365.749 \\
Unigram + Bigram & 235.426 \\
Bigram + Trigram & 568.324 \\
Unigram + Bigram + Trigram & 601.175 \\
\hline
\end{tabular}

Dari tabel di atas dapat dilihat jumlah fitur yang dihasilkan sangat banyak. Hal ini membuat proses pembuatan model klasifikasi memerlukan waktu komputasi yang lama dan kadang data tidak dapat diproses karena limitasi dari memori perangkat keras. Dari permasalahan ini maka perlu dicari dan dikembangkan teknik ekstraksi fitur yang dapat menghasilkan jumlah fitur jauh di bawah jumlah fitur di atas namun masih mampu memberikan kinerja klasifikasi yang bagus.

\section{TINJAUAN PUSTAKA}

Pada bagian ini dijelaskan secara singkat konsep dasar tentang ekstraksi fitur secara umum.

\subsection{Data Terstruktur}

Database adalah salah satu contoh data tersturktur yang terdiri atas kolom dan baris. Baris pada data terstruktur adalah representasi dari sebuah sampel atau obyek. Sedangkan kolom adalah atribut atau fitur dari sebuah sample atau obyek. Sebuah fitur dapat bernilai numerik atau nominal. Setiap data terstruktur memiliki jumlah fitur yang sama dan pada sebuah fitur memiliki tipe data tertentu seperti yang terlihat pada Gambar 2. Untuk kasus klasifikasi, algoritma klasifikasi tidak hanya memerlukan fitur saja namun juga memerlukanclass atau label.

\begin{tabular}{|c|c|c|c|c|c|}
\hline & feature & feature & $\ldots$ & feature & class \\
\hline sample $_{1}$ & value & value & value & value & label1 \\
\hline sample $_{2}$ & value & value & value & value & label1 \\
\hline$\ldots$ & $\ldots$ & $\ldots$ & $\ldots$ & $\ldots$ & $\ldots$ \\
\hline sample $_{\mathbf{n}}$ & value & value & value & value & label2 \\
\hline
\end{tabular}

Gambar 2. Data terstruktur.

\subsection{Vector Space Representation}


Vector space representation adalah teknik ekstraksi fitur yang telah banyak digunakan pada riset klasifikasi teks. Teknik ini membuat teks sebagai data yang tidak terstruktur menjadi data terstruktur dalam bentuk termfrequency matrix [11] [12]. Teknik ini mudah digunakan dan menghasilkan fitur yang sederhana.

Gambar 3 menampilkan bagaimana teknik ini mengubah teks sebagai data tidak terstruktur menjadi bentuk term-frequency matrix. Setiap kata yang ada pada seluruh kalimat menjadi sebuah fitur pada data terstruktur. Nilai dari setiap fitur untuk sebuah dokumen atau sample adalah jumlah kemunculan kata pada sebuah dokumen. Teknik pada gambar ini dikenal dengan istilah unigram. Untuk teknik bigram maka setiap fitur berisi dua kata, dan teknik trigram menggunakan tiga kata sebagai sebuah fitur [6].

\begin{tabular}{|c|c|}
\hline \multicolumn{2}{|c|}{ Unstructured data } \\
\hline d1 & $\begin{array}{l}\text {... the quick } \\
\text { brown ... }\end{array}$ \\
\hline $\mathrm{d} 2$ & $\begin{array}{c}\text { The quick } \\
\text { brown and over } \\
\text { cunny fox ... } \\
\text { the fast }\end{array}$ \\
\hline d3 & $\begin{array}{c}\text {... the fox is } \\
\text { brown and } \\
\text { quick ... }\end{array}$ \\
\hline
\end{tabular}

\begin{tabular}{|c|c|c|c|c|c|c|c|c|c|}
\hline \multicolumn{10}{|c|}{ Structured data } \\
\hline d1 & the & quick & brown & and & over & cunny & fox & is & fast \\
\hline d2 & 2 & 1 & 1 & 0 & 0 & 0 & 0 & 0 & 0 \\
& & & 1 & 1 & 1 & 1 & 1 & 0 & 1 \\
\hline d3 & 1 & 1 & 1 & 1 & 0 & 1 & 1 & 1 & 0 \\
\hline
\end{tabular}

Gambar 3. Struktur data yang dihasilkan oleh teknik unigram.

Teknik lain adalah term frequency and inverse document frequency (TF-IDF). Pendekatan ini masih menggunakan n-gram untuk membuat fitur. Namun teknik ini mempunyai cara yang berbeda untuk menentukan nilai fitur. TF-IDF menghitung bobot dari dua statistik yaitu TF yang menghitung jumlah kemunculan kata pada dokumen dan IDF merupakan perhitungan dari bagaimana kata didistribusikan secara luas pada koleksi dokumen yang bersangkutan.

\subsection{Word2Vec}

Word2vec adalah dua lapisan neural network yang memproses text. Word2vec memiliki dua algoritma belajar yaitu continous bag-of-word dan continuous skip-gram. Dengan algoritma continuous bag-of-words, urutan dari kalimat di dalam riwayat tidak mempengaruhi proyeksi. Algoritma ini memprediksi kata saat ini berdasarkan konteks. Sedangkan algoritma skip-gram memprediksi kata-kata yang berada disekitar suatu kata [15]. Input fungsi word2vec adalah corpus teks dan outputnya adalah set vektor-vektor seperti terlihat pada Gambar 4. Pada gambar dapat dilihat input dapat terdiri dari banyak dokumen. Dan output adalah vektor dari setiap kata yang ada pada dokumen. Jumlah fitur pada vektor dapat ditentukan atau dikontrol jumlahnya. Nilai setiap fitur adalah numerik.

\begin{tabular}{|c|c|}
\hline \multicolumn{2}{|c|}{ Input } \\
\hline $\mathrm{d} 1$, & \\
$\mathrm{d} 2$, & ... the quick \\
$\mathrm{d} 3$ & brown ... \\
& The quick \\
& brown and \\
& over cunny \\
& fox ... the \\
& fast \\
& ... the fox is \\
& brown and \\
& quick ... \\
\hline
\end{tabular}

\begin{tabular}{|c|c|c|c|c|c|c|c|c|c|}
\hline \multicolumn{10}{|c|}{ Output } \\
\hline & f1 & f2 & f3 & f4 & f5 & f6 & f7 & $\ldots$ & fn \\
\hline the & num & num & num & num & num & num & num & $\ldots$ & num \\
\hline quick & num & num & num & num & num & num & num & $\ldots$ & num \\
\hline brown & num & num & num & num & num & num & num & $\ldots$ & num \\
\hline and & num & num & num & num & num & num & num & $\ldots$ & num \\
\hline over & num & num & num & num & num & num & num & $\ldots$ & num \\
\hline cunny & num & num & num & num & num & num & num & $\ldots$ & num \\
\hline fox & num & num & num & num & num & num & num & $\ldots$ & num \\
\hline fast & num & num & num & num & num & num & num & $\ldots$ & num \\
\hline$\ldots$ & num & num & num & num & num & num & num & $\ldots$ & num \\
\hline
\end{tabular}

Gambar 4. Input dan output pada fungsi Word2Vec.

Tujuan dan manfaat word2vec adalah untuk mengelompokkan vektor dari kata yang mirip di dalam ruang vektor. Word2vec membuat vektor yang didistribusikan representasi numerik dari fitur kata. Dengan menggunakan data yang cukup, word2vec data memprediksi secara akurat arti kata berdasarkan riwayat kemunculannya. Prediksi tersebut dapat digunakan untuk menentukan asosiasi sebuah kata dengan kata-kata lainnya yang mirip. Sebagai contoh man berasosiasi dengan boy atau woman berasosiasi dengan girl [16]. 
Teknik ekstraksi fitur data teks dengan menggunakan vektor word2vec yang umum digunakan adalah dengan menghitung rata-rata vektor dari setiap kata yang ada dalam sebuah kalimat [17] dengan rumus seperti pada Rumus 1.

$$
V_{\text {sentance }}(w)=\frac{1}{n} \sum_{i=1}^{n} v_{w i}
$$

Dimana $w$ adalah dokumen atau kalimat yang berisi kata-kata, $n$ adalah jumlah kata pada dokumen $w$ dan $v_{w i}$ adalah vektor dari kata $w i$.

\section{METODOLOGI PENELITIAN}

\subsection{Dataset}

Dataset yang digunakan pada penelitian ini adalah review film IMDB yang juga digunakan pada riset A. Tripathy dan kawan-kawan [6]. Detail dataset ini dapat dilihat pada Tabel 7. Dataset terdiri atas 50.000 review yang dibagi menjadi dua class yaitu positif dan negatif. Seluruh review ini menjadi input untuk fungsi word2vec untuk mendapatkan vektor set dari setiap kata yang ada di dataset. Sedangkan untuk percobaan klasifikasi hanya digunakan 1.000 review positif dan 1.000 review negatif yang dipilih secara random dari 50.000 review. Data diproses untuk menghilangkan angka dan karakter spesial sebelum diproses oleh algoritma klasifikasi.

Tabel 7. Dataset review film IMDB.

\begin{tabular}{cc}
\hline class & jumlah \\
\hline Dataset untuk Word2Vec & \\
\hline Positive & 25.000 \\
Negative & 25.000 \\
\hline \multicolumn{2}{c}{ Dataset untuk percobaan klasifikasi } \\
\hline Positive & 1.000 \\
Negative & 1.000 \\
\hline
\end{tabular}

\subsection{Ekstraksi Fitur dan Klasifikasi}

Seperti disebutkan di atas, word2vec dapat menghasilkan vektor set yang jumlah fiturnya dapat kita tentukan. Pada tahap pertama dibuat model word2ved dengan jumlah fitur yang bervariasi yaitu 3, 10, 25, 50, 100, 300 dan 500. Model ini dibuat dengan menggunakan fungsi word2vec dengan input dataset review film IMDB. Selain itu kita juga menggunakan pre-trained model yang dihasilkan dari dataset Google News yang berisi 100 milyar kata. Pre-trained model ini berisi 3 juta kata dengan jumlah fitur adalah 300.

Setiap vektor set yang dihasilkan disimpan ke dalam file bin. Tabel 8 menampilkan detail file bin dari setiap file yang dibuat. Ukuran file dari setiap file bergantung dengan jumlah fitur dan jumlah kata pada dataset.

Tabel 8. Vektor kata dari dataset film review IMDB dan Google News.

\begin{tabular}{llccc}
\hline $\begin{array}{c}\text { Kode } \\
\text { Model }\end{array}$ & \multicolumn{1}{c}{ Nama File } & $\begin{array}{c}\text { Jumlah } \\
\text { Fitur }\end{array}$ & Dataset & Ukuran File \\
\hline M1 & IMDB.Vector.3.bin & 3 & IMDB movie review dataset & $954 \mathrm{~KB}$ \\
M2 & IMDB.Vector.10.bin & 10 & IMDB movie review dataset & $2.206 \mathrm{~KB}$ \\
M3 & IMDB.Vector.25.bin & 25 & IMDB movie review dataset & $4.888 \mathrm{~KB}$ \\
M4 & IMDB.Vector.50.bin & 50 & IMDB movie review dataset & $9.357 \mathrm{~KB}$ \\
M5 & IMDB.Vector.100.bin & 100 & IMDB movie review dataset & $18.296 \mathrm{~KB}$ \\
M6 & IMDB.Vector.300.bin & 300 & IMDB movie review dataset & $54.052 \mathrm{~KB}$ \\
M7 & IMDB.Vector.500.bin & 500 & IMDB movie review dataset & $89.810 \mathrm{~KB}$ \\
PM1 & GoogleNews-vectors-negative300.bin & 300 & Google news dataset & $3.558 .847 \mathrm{~KB}$ \\
\hline
\end{tabular}


Langkah selanjutnya adalah ekstraksi fitur pada 2.000 review film yang dipilih secara random menjadi data terstruktur. Ada dua pendekatan ekstraksi fitur yang digunakan. Pendekatan yang pertama berdasarkan pendekatan yang digunakan oleh riset Liu dan kawan-kawan [17] seperti yang dapat dilihat pada Gambar 5. Model word2vec yang digunakan pada alur ini bervariasi sesuai dengan model yang telah dibuat pada Tabel 8 , sehingga dihasilnya sejumlah 8 data terstruktur yang diproses oleh algoritma klasifikasi. Pendekatan ini dilakukan untuk mengetahui model vector mana yang dapat membantu meningkatkan kinerja klasifikasi.

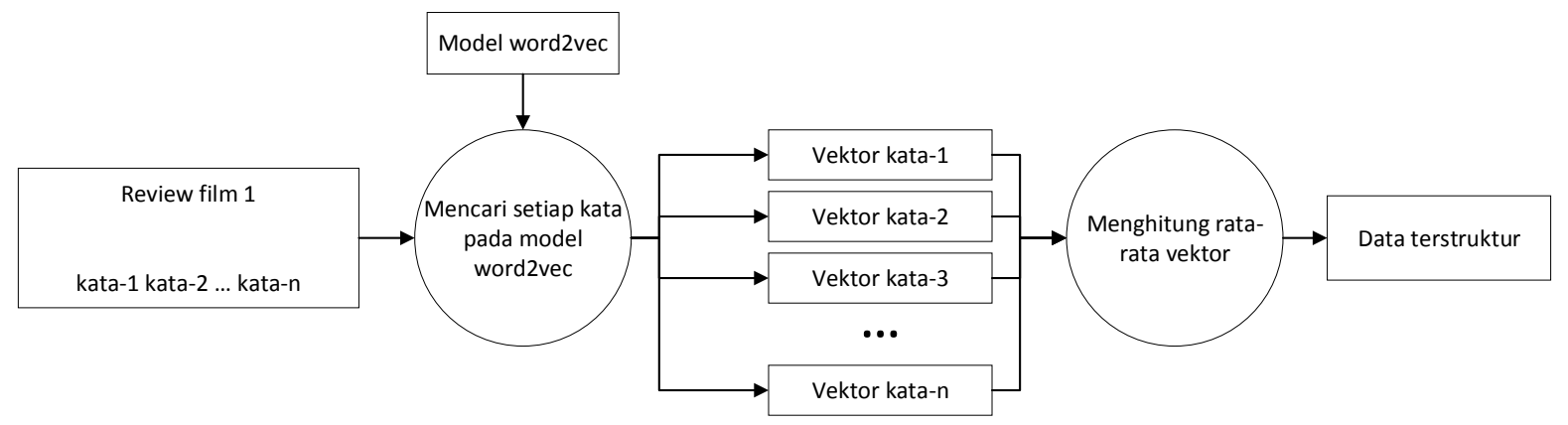

Gambar 5. Ekstraksi fitur pendekatan I.

Kami juga mengajukan pendekatan baru sebagai ekstraksi fitur pendekatan II. Gambar 6 memperlihatkan cara kerja pendekatan ini.

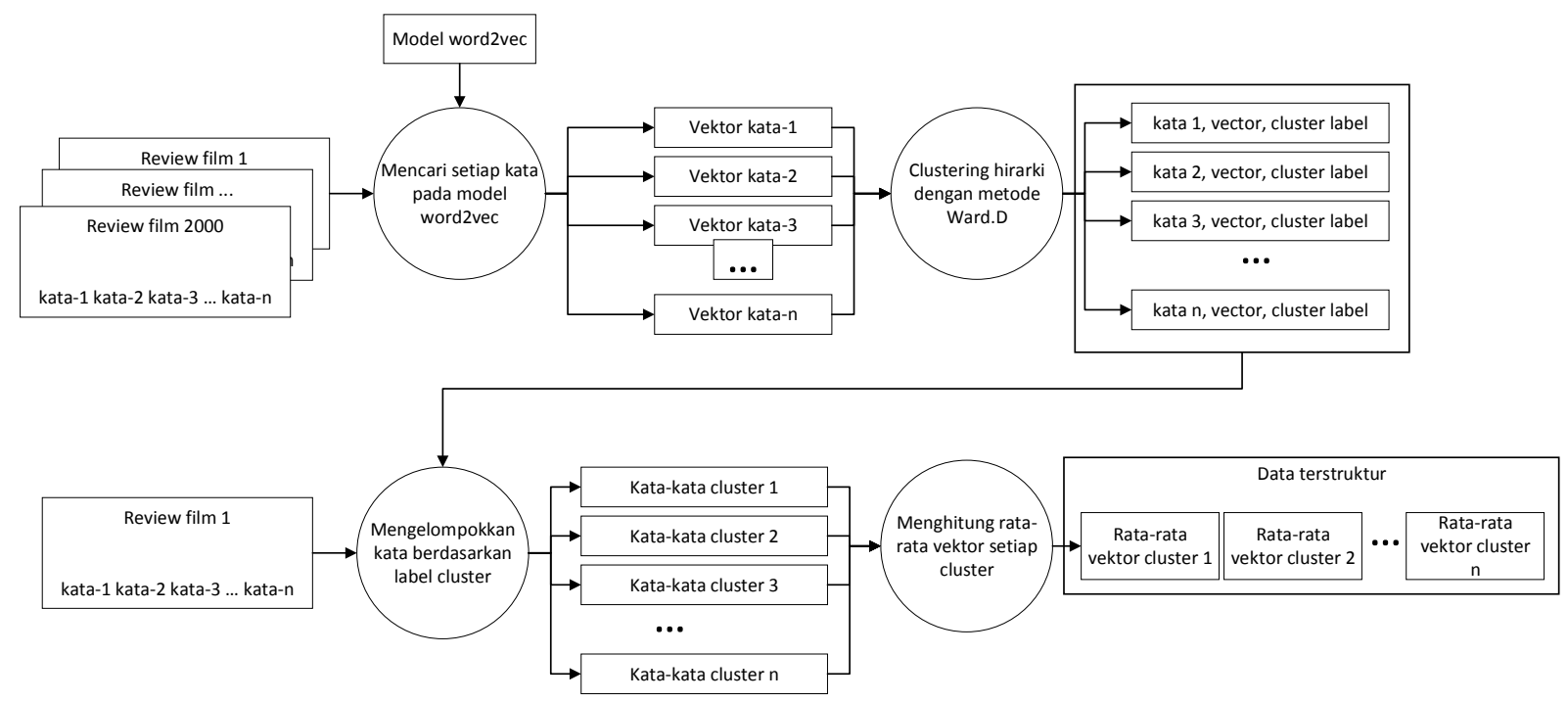

Gambar 6.Ekstraksi fitur pendekatan II.

Pada Gambar 6 dapat dilihat pendekatan ini memiliki dua lapisan. Lapisan pertama melakukan berapa proses yaitu mengumpulkan vektor dari setiap kata yang ada pada 2000 dokumen berdasarkan pencarian ke model word2vec yang telah dibuat pada Tabel 8 . Vektor dari kata-kata tersebut dikelompokkan dengan menggunakan hirarki cluster metode Ward.D dan kemudian memberikan label cluster yang bersesuaian pada setiap vektor. Jumlah cluster yang buat pada riset ini adalah 5 dan 10 saja. Pada lapisan kedua, ekstraksi fitur dilakukan dengan menghitung rata-rata vektor kata pada setiap cluster. Kemudian setiap rata-rata vektor digabungkan dengan cara seperti terlihat pada Gambar 6.

Pada riset ini juga dibentuk fitur dari hasil penggabungan fitur yang dihasilkan pada ekstraksi fitur pendekatan I dan II. 
Setelah semua data terstruktur telah disiapkan maka setiap data terstruktur tersebut diproses dengan algoritma Support Vector Machine (SVM) untuk membuat model klasifikasi. Setiap model diuji dan dihitung kinerjanya dengan menggunakan 10-fold cross-validation. Metrik evaluasi yang digunakan untuk menghitung kinerja adalah akurasi dan Area Under Curve Receiver Operating Characteristics (AUC ROC). Setiap kinerja klasifikasi yang dihasilkan akan dibandingkan untuk mendapatkan pendekatan ekstraksi fitur mana yang menghasilkan kinerja klasifikasi terbaik.

\section{HASIL DAN PEMBAHASAN}

Pada bagian ini diperlihatkan hasil dari teknik ekstrasi fitur yang telah disebutkan pada bagian sebelumnya. Hasil dari ekstraksi fitur pendekatan pertama dapat dilihat pada Gambar 7. Pada gambar dapat dilihat jumlah fitur dan kinerja klasifikasi yang dihasilkan dari setiap model dari pendekatan ini. Secara umum semakin banyak jumlah fitur maka kinerja klasifikasi juga meningkat namun peningkatan kinerja tertinggi sudah dapat dicapai dengan jumlah fitur sebanyak 300 yang dapat dilihat pada kode model M6. Pada gambar ini juga dapat dilihat model yang dibuat dari corpus teks dari review film IMDB lebih bagus jika dibandingkan dengan menggunakan corpus dari Google News yang jumlah kata didalamnya lebih banyak.

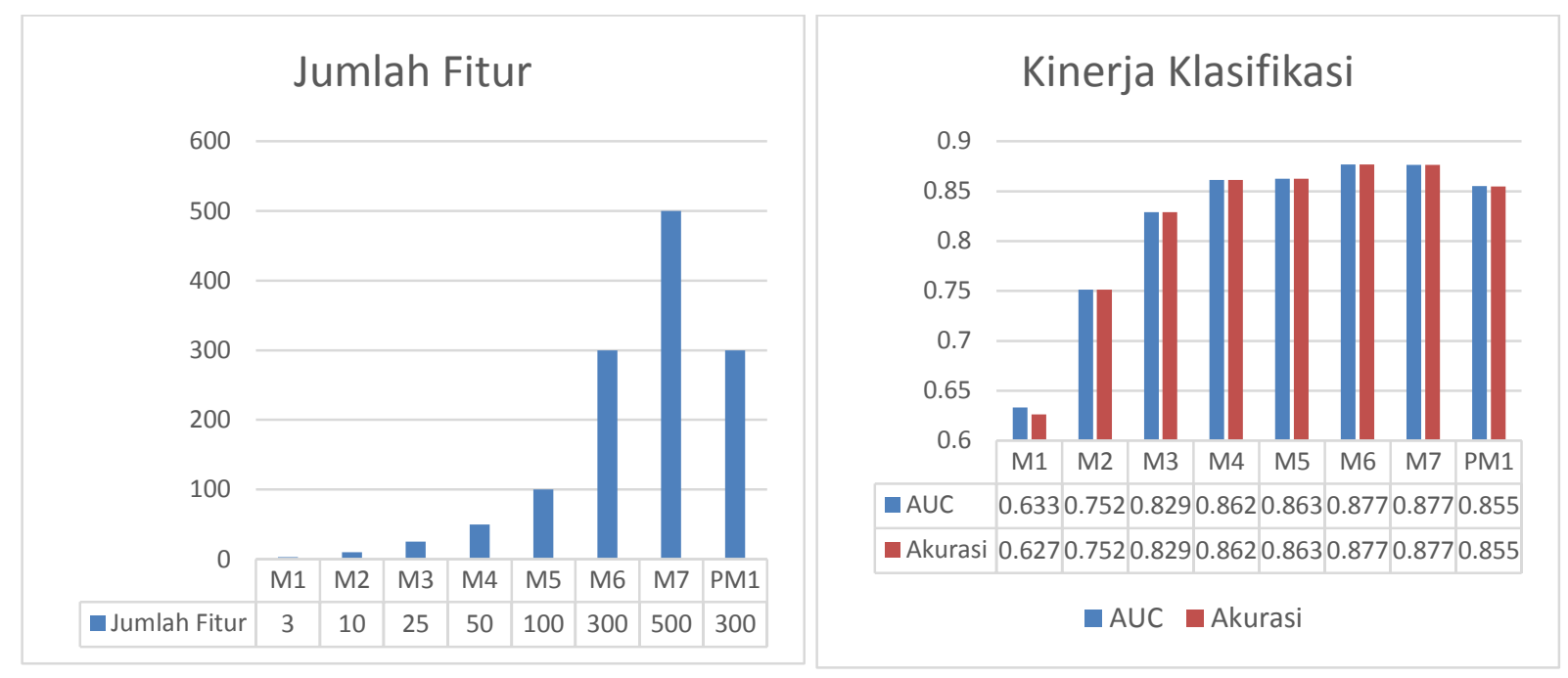

Gambar 7. Jumlah fitur dan kinerja klasifikasi dengan menggunakan ekstraksi fitur pendekatan I.

Tabel 9 memperlihatkan kinerja klasifikasi dengan menggunakan ekstraksi fitur pendekatan II. Pada eksperimen ini hanya tidak digunakan model M1 dan M2 karena nilai kinerja yang rendah pada eksperiment sebelumnya yaitu dibawah 0.8. Kinerja terbaik yang dihasilkan oleh pendekatan II ini adalah saat menggunakan model M6 dengan jumlah cluster 5 yaitu 0.869 dengan jumlah fitur 1500.

Tabel 9. Jumlah fitur dan kinerja klasifikasi dengan menggunakan ekstraksi fitur pendekatan II.

\begin{tabular}{ccccc}
\hline Kode Model & Jumlah Clusters & Jumlah Fitur & \multicolumn{2}{c}{ Kinerja Klasifikasi } \\
& & & AUC & Accuracy \\
\hline M3 & 5 & 125 & 0.8471 & 0.847 \\
M3 & 10 & 250 & 0.831 & 0.831 \\
M4 & 5 & 250 & 0.8636 & 0.8635 \\
M4 & 10 & 500 & 0.8275 & 0.8275 \\
M5 & 5 & 500 & 0.8611 & 0.861 \\
M5 & 10 & 1000 & 0.8421 & 0.842 \\
M6 & $\mathbf{5}$ & $\mathbf{1 5 0 0}$ & $\mathbf{0 . 8 6 9 5}$ & $\mathbf{0 . 8 6 9}$ \\
M6 & 10 & 3000 & 0.8262 & 0.8255 \\
\hline
\end{tabular}

Pada eksperiment ketiga, fitur yang dihasilkan dari dari ekstraksi fitur pendekatan I dan II digabungkan dan didapatkan akurasi 0.8745 dengan jumlah fitur 1.800. Perbandingan nilai terbaik dari ketiga eksperimen yang 
dilakukan dapat dilihat pada Gambar 8. Dari gambar tersebut dapat dilihat jumlah fitur yang paling sedikit dan nilai kinerja klasifikasi terbaik adalah dari eksperimen pertama. Eksperiment ketiga dilakukan dengan asumsi bahwa penggabungan fitur dari eksperiment I dan II diharapkan mampu meningkatkan kinerja klasifikasi, namun pada kenyataannya kinerja menjadi sedikit menurun. Hal ini mungkin disebabkan karena adanya noise pada data hasil penggabungan.

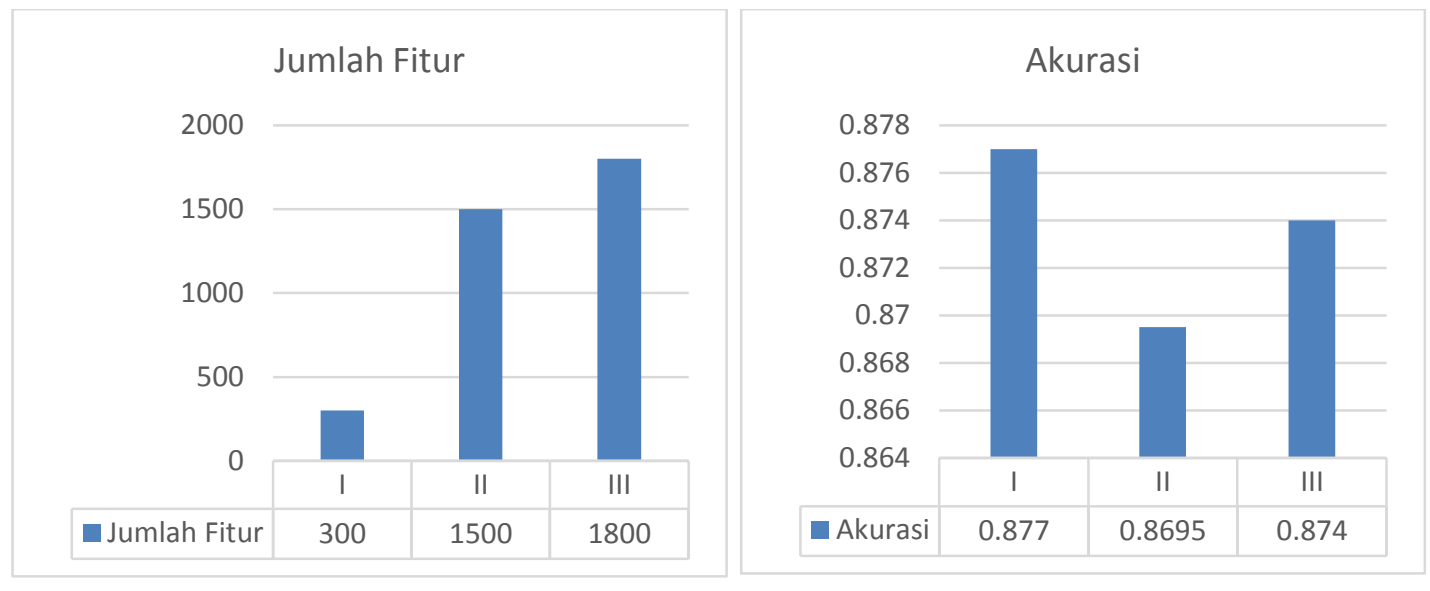

Gambar 8. Perbandingan jumlah fitur dan kinerja klasifikasi.

Namun secara umum nilai akurasi yang dihasilkan dari ketiga eksperimen tersebut dapat dikategorikan sebagai klasifikasi yang bagus karena nilainya di atas 0.8. Hal ini sesuai dengan panduan umum tentang nilai akurasi klasifikasi yang ada [18]. Pada penelitan yang dilakukan oleh A. Tripathy dan kawan-kawan [6] mendapatkan kinerja klasifikasi yaitu akurasi $=0.889$ dengan jumlah fitur yaitu 601.175. Nilai ini lebih tinggi dari semua nilai yang kami lakukan, namun jika dilihat dari jumlah fitur yang dihasilkan eksperimen yang kami hasilnya jauh lebih sedikit yaitu antara 300 - 1.800 fitur saja.

\section{KESIMPULAN}

Tujuan dari penelitian yang kami lakukan adalah mengembangkan teknik ekstraksi fitur yang memanfaatkan vektor word2vec yang mampu menghasilkan data terstruktur dengan jumlah fitur yang dapat ditentukan. Hal ini telah berhasil dilakukan dengan perbandingan jumlah fitur yaitu 4,99\% - 29,95\% dari jumlah fitur yang dihasilkan dari riset terdahulu. Sedangkan perbedaan kinerja klasifikasi yang dihasilkan adalah dengan penelitinan sebelumnya adalah 0.012 lebih rendah dibanding penelitian sebelumnya. Hal ini dapat menjadi riset lanjutan untuk meningkatkan dengan beberapa cara yaitu (i) implementasi seleksi fitur untuk menghilangkan noise pada fitur yang dihasilkan oleh teknik ekstraksi fitur yang telah kami lakukan dan (ii) implementasi algoritma klasifikasi yang lain seperti Random Forest, Deep Learning dan lain-lain, dengan tujuan untuk meningkatkan kinerja klasifikasi.

\section{DAFTAR PUSTAKA}

[1] R. Feldman and J. Sanger, Text Mining Handbook: Advanced Approaches in Analyzing Unstructured Data. New York, NY, USA: Cambridge University Press, 2006.

[2] B. Altınel and M. C. Ganiz, "Semantic text classification: A survey of past and recent advances," Inf. Process. Manag., vol. 54, no. 6, pp. 1129-1153, 2018.

[3] S. G. Burdisso, M. Errecalde, and M. Montes-y-Gómez, "A text classification framework for simple and effective early depression detection over social media streams," Expert Syst. Appl., vol. 133, pp. 182-197, 2019.

[4] M.-A. Kaufhold, M. Bayer, and C. Reuter, "Rapid relevance classification of social media posts in disasters and emergencies: A system and evaluation featuring active, incremental and online learning," Inf. Process. Manag., vol. 57, no. 1, p. 102132, 2020. 
[5] Muhammad Rusli; Mohammad Reza Faisal; Irwan Budiman; Radityo Adi Nugroho; Andi Farmadi, "Ekstraksi Fitur Menggunakan Model Word2vec Pada Sentiment Analysis Kolom Komentar Kuisioner Evaluasi Dosen Oleh Mahasiswa," Kuтрul. J. Ilти Komput., vol. 7, 2020.

[6] A. Tripathy, A. Agrawal, and S. K. Rath, "Classification of sentiment reviews using n-gram machine learning approach,” Expert Syst. Appl., vol. 57, pp. 117-126, 2016.

[7] V. Kolhatkar and M. Taboada, "Using New York Times Picks to Identify Constructive Comments," in Proceedings of the 2017 \{EMNLP\} Workshop: Natural Language Processing meets Journalism, 2017, pp. 100-105.

[8] M. R. Faisal et al., "Improving Protein Sequence Classification Performance Using Adjacent and Overlapped Segments on Existing Protein Descriptors," J. Biomed. Sci. Eng., vol. 11, no. 06, pp. 126-143, 2018.

[9] D. Phan et al., "Combined Use of k-Mer Numerical Features and Position-Specific Categorical Features in Fixed-Length DNA Sequence Classification," J. Biomed. Sci. Eng., vol. 10, no. 08, pp. 390-401, 2017.

[10] N. G. Nguyen et al., "DNA Sequence Classification by Convolutional Neural Network," J. Biomed. Sci. Eng., vol. 09, no. 05, pp. 280-286, 2016.

[11] D. J. Hand, P. Smyth, and H. Mannila, Principles of Data Mining. Cambridge, MA, USA: MIT Press, 2001.

[12] C. D. Manning, P. Raghavan, and H. Schütze, Introduction to Information Retrieval. New York, NY, USA: Cambridge University Press, 2008.

[13] G. SALTON, "Developments in Automatic Text Retrieval," Science (80-. )., vol. 253, no. 5023, pp. 974-980, 1991.

[14] A. Onan, S. Korukoğlu, and H. Bulut, "Ensemble of keyword extraction methods and classifiers in text classification,” Expert Syst. Appl., vol. 57, pp. 232-247, 2016.

[15] J. Lilleberg, Y. Zhu, and Y. Zhang, "Support vector machines and Word2vec for text classification with semantic features," in 2015 IEEE 14th International Conference on Cognitive Informatics Cognitive Computing $\left(I C C I^{*} C C\right), 2015$, pp. 136-140.

[16] C. Nicholson, “A Beginner's Guide to Word2Vec and Neural Word Embeddings,” 2019. [Online]. Available: https://skymind.ai/wiki/word2vec. [Accessed: 10-May-2019].

[17] H. Liu, "Sentiment Analysis of Citations Using Word2vec," 2017.

[18] K. Gao, T. Khoshgoftaar, and R. Wald, "Combining Feature Selection and Ensemble Learning for Software Quality Estimation.” 2014. 